\title{
Ventrogluteal Alana İntramüsküler Enjeksiyon Uygulamasına Yönelik Hemşirelere ve Ebelere Verilen Eğitimde Nöro Linguistik Programlama Tekniğinin Etkisi
}

\author{
Sinem Eroğlu ${ }^{1} \odot$, Kıvan Çevik² ${ }^{2}$
}

'Manisa Celal Bayar Üniversitesi, Sağlık Bilimleri Enstitüsü, Manisa, Türkiye

${ }^{2}$ Manisa Celal Bayar Üniversitesi, Sağlık Bilimleri Fakültesi, Hemşirelik Bölümü, Manisa,Türkiye

Sinem Eroğlu, Uzm. Hemş. Kıvan Çevik, Dr. Öğr. Üyesi

Yüksek lisans tezinden oluşturulmuş bu çalışma IV. Uluslararası ve VIII. Ulusal Psikiyatri Hemşireliği Kongresi, 06- 09 Kasım 2016, Manisa' da poster bildiri olarak sunulmuştur.

İletişim:

Uzm. Hemş. Sinem Eroğlu Manisa Celal Bayar Üniversitesi, Sağık Bilimleri Enstitüsü, Manisa, Türkiye Tel: +905544160378

E-Posta: sinemcitakeroglu@gmail.com

Gönderilme Tarihi : 160 cak 2018

Revizyon Tarihi : 26 Mart 2018

Kabul Tarihi : 26 Mart 2018
ÖZET

Amaç: Ventrogluteal alana intramüsküler enjeksiyon uygulamasına yönelik hemşirelere ve ebelere verilen eğitimde Nöro Linguistik Programlama tekniklerinin etkisini belirlemek amacılla yapılmış deneysel bir çalışmadır.

Yöntem: Araştırma, 18 Mayıs - 21 Eylül 2015 tarihleri arasında bir devlet hastanesinde görev yapan hemşireler ve ebelerle yürütüldü. Örneklem seçimine gidilmeyip araştırmaya katılmayı kabul eden ve NLP'ye ilişkin eğitim almayan tüm ebe ve hemşireler araştırmaya alındı. Verilerin toplanmasında ilgili literatür doğrultusunda araştırmacı tarafından geliştriilen, "Hemşire ve Ebe Tanıtım Formu”, "Hemşirelerin ve Ebelerin İntramüsküler Enjeksiyon Uygulamasına Ilişkin Görüşleri Formu" ve "Ventrogluteal Bölgeye lilşkin Bilgi Formu" kullanıı Rı. Araştırmadan elde edilen veriler (SPSS) 22.0 programında sayı, yüzde, ortalama, paired $t$ testi, student $t$ testi, ki kare testi, Kruskal-Wallis, Mann-Whitney U ve Mc-Nemar Testi kullanilarak değerlendirildi.

Bulgular: Araştırmaya katılan hemşirelerin ve ebelerin yaş ortalaması deney grubunda $35.84 \pm 6.13$, kontrol grubunda $39.29 \pm 7.91$ olduğu, deney grubunda \%93.3'ünün kadın, \%6.7'sinin erkek, kontrol grubunda \%100'ünün kadın olduğu, intramüsküler enjeksiyonlarda en sık kullandıkları bölgenin deney grubunda (\%95.6) ve kontrol grubunda (\%88.9) dorsogluteal bölge olduğu saptandı. Ventrogluteal bölgeye ilişkin bilgi puan ortalamaları deney grubunda NLP tekniği ile verilen eğitim öncesi $14.29 \pm 8.34$, eğitim sonrası $23.53 \pm 3.14$ olduğu, kontrol grubunda standart eğitim öncesi $10.38 \pm 8.87$, eğitim sonrası $18.76 \pm 6.80$ olduğu saptandı.

Sonuç: Araştırma bulguları doğrultusunda, verilen eğitimde NLP tekniğinin etkili olmadı̆ı söylenebilir.

Anahtar sözcükler: Nöro Linguistik Program, Ventrogluteal Bölge, Eğitim

THE EFFECT OF NEURO LINGUISTIC PROGRAMMING (NLP) TECHINIQUES ON NURSES AND MIDWIVES ON INTRAMUSCULAR INJECTION APPLICATION IN THE VENTROGLUTEAL AREA.

\section{ABSTRACT}

Aim: This is an experimental study to determine the effect of Neuro-Linguistic Programming techniques on nursing and midwifery training for intramuscular injection in the ventrogluteal area.

(The aim of this study was to determine the effect of neuro-linguistic programming techniques on the training of nurses and midwives for intramuscular injection in the ventrogluteal area).

Methods: The study was achived with nurses and midwives who are employed in Uşak Government Hospital between May 18 - September 21,2015 . In this research, sampling choice wasn't done, nurses who didn't get the NLP training before and agreed to participate were included in the study.

Data were collected using the form which was prepared by the researchers, "Nurses and midwives Description Form”, ${ }^{\prime \prime} T$ The Perceptions of Nurses and midwives about Intramuscular Injection Application" and "Ventrogluteal Area Knowledge Form". The data were analyzed with numbers, percentages, means, paired t test, student's t test, chi- square test, Kruskal-Wallis, Mann-Whitney U and MC-Neamer tests using the SPSS 22.0 software package.

Conclusion: The average (mean)age of nurses and midwives on the test group was $35.84 \pm 6.13$, on the control group $39.29 \pm 7.91$. On the test group, $93.3 \%$ of participants were femalesand $6.7 \%$ were males. On the control group, $100 \%$ of participants were females. The most used area for IM injections was the dorsogluteal area on the test group (95.6\%) and the control group (88.9\%). Knowledge point average of nurses and midwives was $14.29 \pm 8.34$ on the test group before training, and after training $23.53 \pm 3.14$ whereas on the control group, before training $10.38 \pm 8.87$, and after training $18.76 \pm 6.80$.

Results: The research findingsare said to be NLP technique was not effective.

Key words: Neuro Linguistic Program, Ventrogluteal Area, Training. 
T eknolojinin gelişmesiyle giderek daha karmaşık bir hale gelen ilaç uygulamaları, hasta güvenliğinin öncelikli olduğu, hemşirelik işlevlerinin önemli bir parçası olan ve bilgi-beceri gerektiren uygulamalardır (1). Dünyada her alanda gözlenen değişim ve gelişmeler, sağlık alanına ve dolayısı ile hemşireliğe de yansımaktadır. Hemşirelerin bu değişim ve gelişmelere uyum sağlamasında, bilimselliği temel almaları ve uygulamalarını kanıta dayandırmaları vazgeçilmez bir ölçüttür (2). İlaç uygulamalarında önemli bir yeri olan intramüsküler (IM) enjeksiyon uygulaması hemşirelerin sıklıkla kullandığı bir yöntemdir (3). Cornwall (2011) hemşirelik öğrencileri üzerinde yaptığı çalışmada hemşirelik öğrencilerinin güvenli IM enjeksiyon bölgelerini tam anlamadıklarını ve güncel öğretim uygulamalarının gözden geçirilmesinin IM enjeksiyondan kaynaklanan patolojileri önlemeye yardımcı olacağını bildirmiştir (4). Hemşirelerin kendilerini güncel tutamadıkları takdirde sadece kendi gelişimlerini engellemekle kalmayacakları, aynı zamanda rehberlik ettikleri öğrencilerin doğru yaklaşım ve uygulamaları ile çelişebilecekleri bildirilmektedir (5).

Gelişmekte olan ülkelerdeki sağlık çalışanları alternatif yöntemlerin veya oral ilaç vermenin aynı etkiyi gösterdiğini ve hatta daha güvenli olduğunu bilmesine karşın yine de enjeksiyonu tercih etmektedir $(6,7)$. Enjeksiyon uygulamalarında kullanılan en yaygın tedavi yöntemi kas içi enjeksiyondur $(8,9)$. Dünya genelinde her yıl 12 milyardan fazla ilaç IM yolla uygulanmaktadır $(10,11)$. Bunların \%5'i veya daha azı aşılama, \%95'inden fazlası da tedavi amacıyla uygulanan enjeksiyonlardır (8). IM enjeksiyon basit bir beceri olarak algılanmaktadır. Ancak, hemşirelerin beceri yeteneği, uygulama yöntemi ve kulIanılan araçlar ile ilgili bazı kararları gerektiren karmaşık bir işlevdir (11). VG bölge ilk kez 1954'de Hochsetter tarafından tanımlanmıştır (11). Derindir ve büyük kan damarları ve sinirlerden uzak olduğundan bütün hastalar için güvenli bölgedir $(1,12,13,14,15)$. Bölge, hastaya verilecek pozisyonun kolay olması, subkütan tabakanın ince olması, cilt altı yağ dokusunun az olması ve ilacın subkütan dokuya verilme olasılığının düşük olması ve bu sayede de hematom oluşumunun en az görülmesi sebepleri ile tercih edilir. Kemik çıkıntıları elle rahatlıkla hissedilebildiği için bölgenin belirlenmesi kolaydır. Rektumdan uzak olduğu için feçes kontaminasyonu riski azdır $(1,16)$. Ventrogluteal bölgenin kas içi enjeksiyon için en güvenli bölge olduğu belirlenmiş olsa da, sağlık personellerinin sıklıkla kalça bölgesini kullandığı bildirilmektedir $(8,9,11,17,18)$. Hemşireler komplikasyonları önlemek için; anatomiyi, enjeksiyon bölgesinin avantaj ve dezavantajlarını, doğru anatomik yerler ve bölge sınırlarını tespit edebilmeyi, enjeksiyon tekniğinin ayrıntılarını ve tekniği dikkatli kullanarak enjeksiyonu yönetmesi gerektiğini bilmelidir (19). Yapılan çalışmalarda, intramüsküler enjeksiyondan kaynaklanan komplikasyonların sıklıkla görüldüğü ve bu komplikasyonların birçoğunun bilgi eksikliği ve uygun olmayan tekniğin kullanılmasından kaynaklandığı saptanmaktadır (12).

Nöro-Linguistik Programlama (NLP) tekniği, başarıya ulaşmak ve kişisel mükemmelliği yakalamak isteyen insanların değiştirmesi gereken tutum ve inançlarını değiştirmeyi kolaylaştırarak kişisel hedeflere başarılı bir şekilde ulaşmasını sağlayan; duygu, düşünce, dil ve davranışların etkin kullanımına odaklanan bir tekniktir $(20,21,22,23)$. NLP'nin etkin olarak kullanıldığı ve sihirli bir araç olarak görüldüğü alanlardan birisi de eğitimdir (22). NLP teknikleri eğitim sürecinde davranışların oluşumunda algıların ve düşünce modellerinin ele alınmasına olanak sağladığı için giderek önem kazanmaktadır (23). Dış dünyadan edindiğimiz deneyimleri beş duyumuzla nasıl bir süzgeçten geçireceğimizi ve aynı içsel duygularımızı, arzuladığımız sonuçlara ulaşmak için bilerek ya da bilmeyerek nasıl kullanacağımızı, durumu tam olarak kavrayabilmemiz için ona farklı açılardan bakmamız gerektiğini konu almaktadır. Buradaki önemli nokta, nasıl algıladığımız ya da nasıl düşündüğümüzle ilgilidir. Düşüncelerimiz (algılarımız, hayal gücümüz ve inanç kalıplarımız) ne yaptığımızı ve ne düşündüğümüzü belirlemektedir $(20,23,24,25)$. NLP'nin temelini uyum ve esneklik oluşturur ve NLP'yi kullanarak; beyni etkin kullanmak, pozitif düşünmek, istenmeyen davranışları değiştirmek, hedef belirleyip sonuç almak, özgüven kazanmak, içsel kaynakların ve zihinsel süreçlerin farkında olmak, başarı ve motivasyon tekniklerini uygulamak gibi yararları olan birçok başarıya ulaşılabilir $(27,28)$.

NLP, öğrenmeye motive olunduğunda ve uygun şekilde ilgili bilgi sunulduğunda kolayca öğrenebileceğimizi vurgular. Günümüzde eğitim alanı NLP'nin kullanıldığı alanların başında gelmektedir. Çevik ve ark. (2017) Santral venöz kateter uygulamaları ve kan kültürü alınması konusunda hemşirelere verilen eğitimde NLP tekniğinin etkili olduğunu saptamışlardır (29). NLP ile ilgili yapılan birçok bilimsel çalışma olumlu sonuçlar vermiştir $(21,22,23,29)$. Hemşirelikte istenilen bilgi, beceri ve tutum değişikliğinin sağlanmasında, NLP tekniklerinden bir öğretim stratejisi olarak yararlanılabilir (23). Hemşirelere ve ebelere verilen eğitimde Nöro Linguistik Programlama tekniklerinin etkinliğini belirlemek amacıyla bu çalışma planlandı. 


\section{Yöntem}

Araştırma deneysel bir çalışma olup, 18 Mayıs - 21 Eylül 2015 tarihleri arasında bir devlet hastanesinde gerçekleştirildi. Araştırmanın evrenini, hastanede görev yapan 649 hemşire ve ebe, araştırmanın örneklemini ise, hastanede görev yapan örneklem seçme ölçütlerine uyan, hemşirelik ve ebelik bölümü mezunu olan, intramüsküler enjeksiyon uygulaması olan kliniklerde çalışan, daha önce NLP ile ilgili eğitime katılmamış olan ve araştırmaya katılmayı kabul eden 45 deney 45 kontrol grubunda olmak üzere toplam 90 hemşire ve ebe oluşturdu. NLP teknikleriyle birlikte verilen eğitim, standart eğitime göre daha uzun sürmektedir. Kurumun çalışma şartlarına göre eğitime katılabilen ancak süre sıkıntısı nedeniyle eğitimden erken ayrılmak zorunda kalan hemşire ve ebeler kontrol grubunu, süre sıkıntısı olmayıp eğitime kalan hemşire ve ebeler ise deney grubunu oluşturdu.

\section{Veri toplama araçları}

Verilerin toplanmasında araştırmacı tarafından ilgili literatür doğrultusunda hazırlanan 3 bölümden oluşan anketler kullanıldı. Birinci bölümde hemşirelerin ve ebelerin sosyodemografik özellikleri ve mesleki özelliklerini saptayan 12 sorunun yer aldığı "Hemşire ve Ebe Tanıtım Formu", ikinci bölümde hemşirelerin ve ebelerin intramüsküler enjeksiyon uygulamasına ilişkin görüşlerinin yer aldığı 12 sorudan oluşan "Hemşirelerin ve Ebelerin İntramüsküler Enjeksiyon Uygulamasına İlişkin Görüşleri Formu", üçüncü bölümde hemşirelerin ve ebelerin ventrogluteal bölgeye yönelik bilgilerini değerlendirmek amacıyla araştırmacı tarafından ilgili literatür doğrultusunda oluşturulmuş 15 doğru ve 15 yanlış önermenin bulunduğu "Ventrogluteal Bölgeye İlişkin Bilgi Formu" kullanıldı(2,3,8,12,13,15,18,30,31,32,33,34,35). " "Ventrogluteal Bölgeye İlişkin Bilgi Formu" nda yer alan sorulara verilen her bir doğru yanıt "1 puan", yanlış yanıt ve fikrim yok seçeneği ise "0 puan" verilerek değerlendirildi. Ventrogluteal bölgeye ilişkin bilgi formu kullanılarak hemşirelerin ve ebelerin bilgi puan ortalamaları alındı. Bilgi puanların yüksek olması ventrogluteal bölgeye ilişkin bilgi düzeylerinin yüksek olduğu anlamına gelmektedir. 0-10 puan arası yeterli düzeyde bilgisinin olmadığı, 11-20 puan arası bilgisinin orta düzeyde olduğu, 21 ve üzeri puan ise iyi düzeyde bilgiye sahip olduğu şeklinde değerlendirildi.

\section{Araştırmanın etik yönü}

Çalışmanın uygulanabilmesi için Manisa Celal Bayar Üniversitesi Tıp Fakültesi Yerel Etik Kurulundan gerekli izinler ve araştırmaya katılmayı kabul eden hemşirelere ve ebelere araştırmaya ilişkin bilgi verildikten sonra sözel izin ve bilgilendirilmiş gönüllü olur formu kullanılarak yazılı izin alındı.

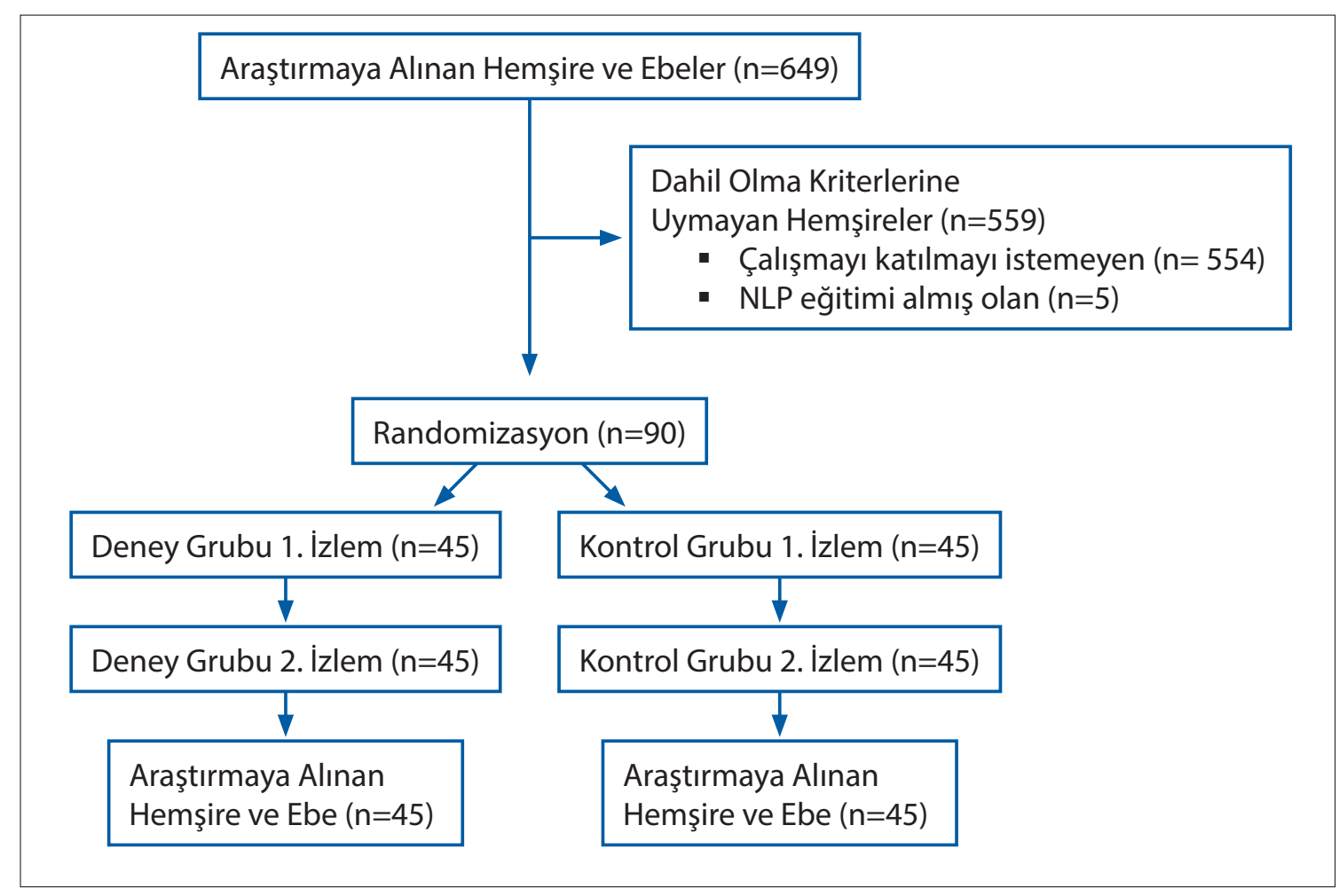

Şekil 1. Deney ve kontrol grubu hemşirelerin ve ebelerin randomizasyon şeması 


\section{Veri analizi}

Araştırmacı tarafından geliştirilen form içeriklerinin anlaşılırlığını değerlendirmek amacıyla 5 uzman ve 5 hemşire ile yapılan ön uygulama sonrasında veri toplama formları ile ilgili gerekli düzeltmeler yapıldı. Ventrogluteal Bölgeye İlişkin Bilgi Formu'ndaki sorular için Cronbach's Alpha güvenilirlik katsayısı (a) eğitim öncesi için 0.942, eğitim sonrası için 0.870 olarak saptandı. Araştırmadan elde edilen veriler Statistical Package For Social Science (SPSS) 22.0 programında sayı, yüzde, ortalama, paired t testi, student t testi, ki kare testi, Kruskal-Wallis, Mann-Whitney U, McNemar Testi ve wilcoxon testi kullanılarak değerlendirildi.
Veri toplama süreci

Şema 2. Araştırma Uygulama Adımları

\section{Bulgular}

Araştırmaya katılan deney grubundaki hemşirelerin ve

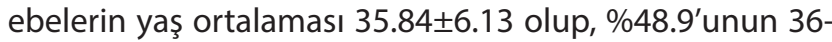
45 yaş grubu arasında, \%93.3'ünün kadın, \%6.7'sinin erkek, \%48.9'unun önlisans mezunu, \%80'inin evli ve \%42.2'sinin iki çocuğu olduğu saptandı (Tablo 1).

Araştırmaya katılan kontrol grubundaki hemşirelerin ve ebelerin yaş ortalaması 39.29+7.91 olup, \%51.1'inin 36-45

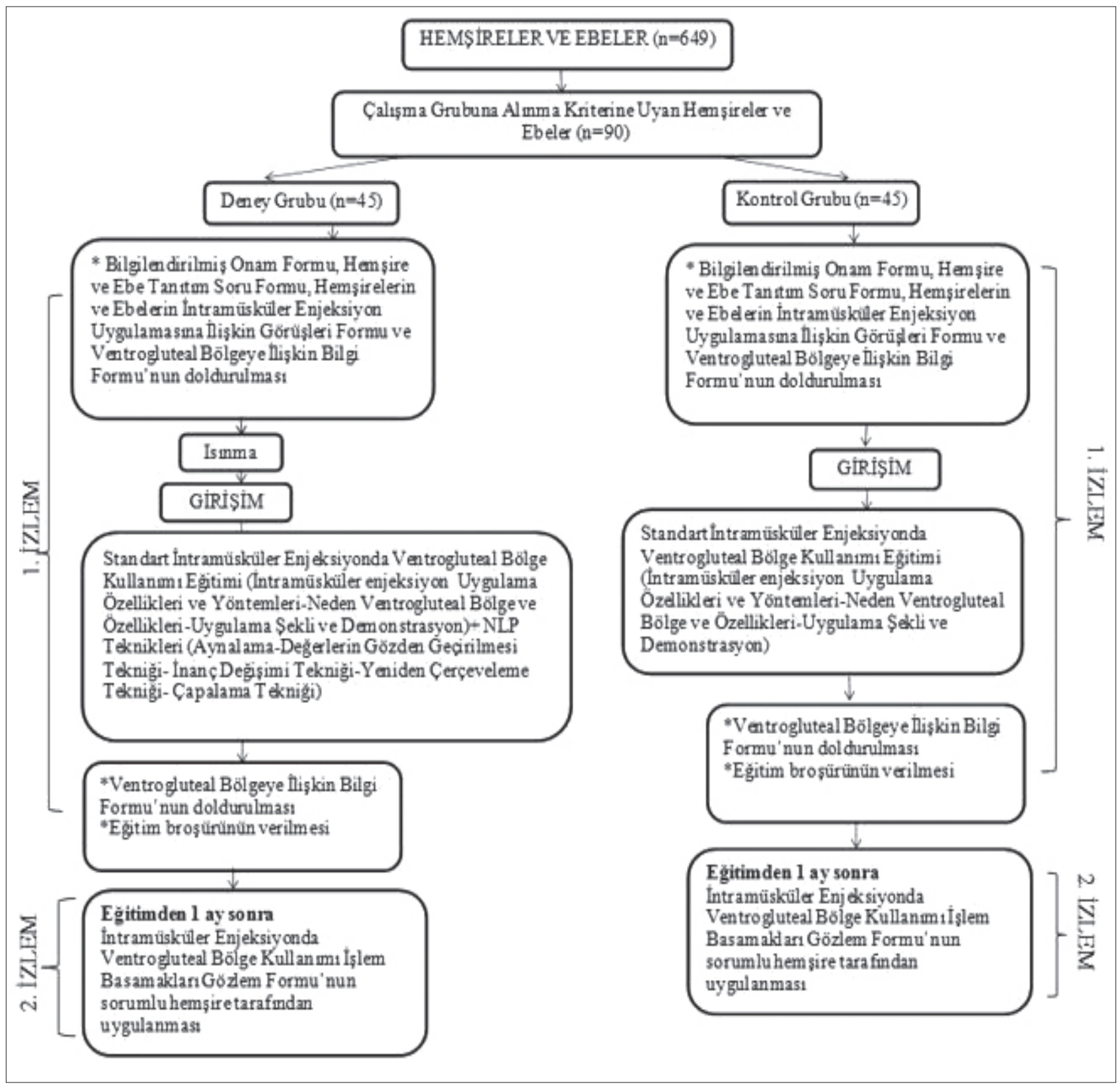

Şekil 2. Araştırma Uygulama Adımları 
yaş grubu arasında, \%100'ünün kadın, \%42.2'sinin lisans mezunu, \%93.3'ünün evli ve \%57.,8'inin iki çocuğu olduğu saptandı (Tablo 1).

Hemşirelerin ve ebelerin intramüsküler uygulamalarda en çok ve en az hangi bölgeyi kullandıkları incelendiğinde; en çok kullandıkları bölgenin deney grubunda (\%95.6) ve kontrol grubunda (\%88.9) dorsogluteal bölgenin olduğu, en az kullandıkları bölgenin deney grubunda (\%40) ve kontrol grubunda (\%40) ventrogluteal bölgenin olduğu saptandı (Tablo 2).

Hemşirelerin ve ebelerin intramüsküler uygulamalarda en güvenli bölgenin hangisi olduğu incelendiğinde; deney grubunda (\%57.8) ve kontrol grubunda \%71.1 ile dorsogluteal bölge olduğu saptandı. Deney ve kontrol grubundaki hemşire ve ebelerin intramüsküler uygulamalarda en güvenli seçtikleri bölgeye göre arasında istatistiksel olarak anlamlı bir fark olmadığı bulunmadı (Tablo 2).

Hemşirelerin ve ebelerin intramüsküler uygulamalar konusunda yeterli bilgi sahibi olma durumu incelendiğinde; deney grubunun \%84.4'ünün evet; kontrol grubunun \%75.6'sının evet cevabını verdiği, gruplar arası karşılaştırıldığında istatistiksel olarak anlamlı bir fark bulunmadığı saptandı (Tablo 2).

Hemşirelerin ve ebelerin intramüsküler uygulamalarda hava kilidi tekniğini kullanma durumu incelendiğinde; deney grubunun \%55.6'sının evet; kontrol grubunun \%51.1'inin hayır cevabını verdiği, gruplar arası karşılaştırıldığında istatistiksel olarak anlamlı bir fark bulunmadığı saptandı (Tablo 2).

Tablo 1. Deney ve kontrol grubundaki hemşirelerin ve ebelerin sosyodemografik özelliklerine göre dağılımı

\begin{tabular}{|c|c|c|c|c|c|c|c|c|}
\hline \multicolumn{9}{|c|}{ Grup } \\
\hline \multirow[t]{2}{*}{$\begin{array}{l}\text { Sosyodemografik } \\
\text { Özellikler }\end{array}$} & & \multicolumn{2}{|c|}{$\begin{array}{c}\text { Deney } \\
(n=45)\end{array}$} & \multicolumn{2}{|c|}{$\begin{array}{l}\text { Kontrol } \\
(n=45)\end{array}$} & \multirow[t]{2}{*}{$\begin{array}{l}\text { Toplam } \\
(n=90)\end{array}$} & \multirow[t]{2}{*}{ Test } & \multirow[t]{2}{*}{$p$} \\
\hline & & $n$ & $\%$ & $n$ & $\%$ & & & \\
\hline & & \multicolumn{2}{|c|}{$O r t \pm S S$} & \multicolumn{2}{|c|}{$O r t \pm S S$} & & & \\
\hline Yaş & & \multicolumn{2}{|c|}{$35.84 \pm 6.13$} & \multicolumn{2}{|c|}{$39.29 \pm 7.91$} & & $t=2.308$ & $0.029 *$ \\
\hline \multirow[t]{4}{*}{ Yaş Grubu } & $18-25$ & 3 & $\% 6.7$ & 4 & $\% 8.9$ & 7 & $X^{2}=9.345$ & $0.022^{*}$ \\
\hline & $26-35$ & 18 & $\% 40.0$ & 8 & $\% 17.8$ & 26 & & \\
\hline & $36-45$ & 22 & $\% 48.9$ & 23 & $\% 51.1$ & 45 & & \\
\hline & 46 ve üstü & 2 & $\% 4.4$ & 10 & \%22.2 & 12 & & \\
\hline \multirow[t]{2}{*}{ Cinsiyet } & Kadın & 42 & \%93.3 & 45 & $\% 100.0$ & 87 & $X^{2}=3.103$ & 0.242 \\
\hline & Erkek & 3 & $\% 6.7$ & 0 & $\% 0.0$ & 3 & & \\
\hline \multirow[t]{4}{*}{ Eğitim Durumu } & Lise & 8 & $\% 17.8$ & 4 & $\% 8.9$ & 12 & $X^{2}=3.525$ & 0.342 \\
\hline & Önlisans & 22 & $\% 48.9$ & 18 & $\% 40.0$ & 40 & & \\
\hline & Lisans & 13 & $\% 28.9$ & 19 & $\% 42.2$ & 32 & & \\
\hline & Lisansüstü & 2 & $\% 4.4$ & 4 & $\% 8.9$ & 6 & & \\
\hline \multirow[t]{3}{*}{ Medeni Durumu } & Evli & 36 & $\% 80.0$ & 42 & $\% 93.3$ & 78 & $X^{2}=3.573$ & 0.187 \\
\hline & Bekar & 7 & $\% 15.6$ & 2 & $\% 4.4$ & 9 & & \\
\hline & Boşanmış / Eşi ölmüş & 2 & $\% 4.4$ & 1 & $\% 2.2$ & 3 & & \\
\hline \multirow[t]{5}{*}{ Çocuk Sayısı } & Yok & 10 & \%22.2 & 6 & \%13.3 & 16 & $X^{2}=2.956$ & 0.406 \\
\hline & Bir & 14 & $\% 31.1$ & 10 & \%22.2 & 24 & & \\
\hline & İki & 19 & $\% 42.2$ & 26 & $\% 57.8$ & 45 & & \\
\hline & Üç & 2 & $\% 4.4$ & 3 & $\% 6.7$ & 5 & & \\
\hline & Diğer & 0 & $\% 0.0$ & 0 & $\% 0.0$ & 0 & & \\
\hline
\end{tabular}

Independent T Test (Bootstrap) - Fisher Exact Test (Monte Carlo) - Pearson Chi Square Test(Monte Carlo) - Linear-by-Linear Association(monte Carlo) ${ }^{*} \mathrm{p}<0.05$

$\mathrm{x}^{2}$ ve $\mathrm{t}$ : test istatistiği 
Hemşirelerin ve ebelerin intramüsküler uygulamalarda Z tekniğini kullanma durumu incelendiğinde; deney grubunun \%57.8'inin hayır; kontrol grubunun \%51.1'inin evet cevabını verdiği, gruplar arası karşılaştırıldığında istatistiksel olarak anlamlı bir fark bulunmadığı saptandı (Tablo 2).

Hemşirelerin ve ebelerin intramüsküler uygulamalarda VG bölge tespiti konusunda demonstrasyon yapma durumu incelendiğinde; deney grubunun \%64.4'ünün hayır; kontrol grubunun \%68.9'unun hayır cevabını verdiği, gruplar arası karşılaştırıldığında istatistiksel olarak anlamlı bir fark bulunmadığı saptandı (Tablo 2 ).
Hemşirelerin ve ebelerin intramüsküler uygulamalarda en son eğitim alma durumu incelendiğinde; deney grubunun $\% 66.7$ 'sinin 13 ay ve üstü; kontrol grubunun \%53.3'ünün 13 ay ve üstü öncesinde eğitim aldığı saptandı. Deney ve kontrol grubunun intramüsküler uygulamalarda en son eğitim alma durumu karşılaştırıldığında; gruplar arasında istatistiksel olarak anlamlı bir fark olmadığı saptandı (Tablo 2).

Hemşirelerin ve ebelerin intramüsküler uygulamalarda VG bölgeyi kullanma durumu incelendiğinde; deney grubunun \%71.1'inin; kontrol grubunun ise \%75.6'sının hayır cevabını verdiği ve gruplar arasında istatistiksel olarak anlamlı bir fark olmadığı saptandı ( $p=0.812$; Tablo 3$)$.

Tablo 2. Deney ve kontrol grubundaki hemşirelerin ve ebelerin intramüsküler enjeksiyon uygulamasına ilişkin görüşleri

\begin{tabular}{|c|c|c|c|c|c|c|c|c|}
\hline \multicolumn{9}{|c|}{ Grup } \\
\hline & & \multicolumn{2}{|c|}{ Deney } & \multicolumn{2}{|c|}{ Kontrol } & \multirow[t]{2}{*}{ Toplam $(n=90)$} & \multirow[t]{2}{*}{$X^{2}$} & \multirow[t]{2}{*}{$p$} \\
\hline & & $n$ & $\%$ & $n$ & $\%$ & & & \\
\hline \multirow[t]{5}{*}{ En Sık Uygulandığı Bölge } & Dorsogluteal & 43 & $\% 95.6$ & 40 & $\% 88.9$ & 83 & 2.308 & 0.356 \\
\hline & Ventrogluteal & 2 & $\% 4.4$ & 3 & $\% 6.7$ & 5 & & \\
\hline & Vastuslateralis & 0 & $\% 0.0$ & 0 & $\% 0.0$ & 0 & & \\
\hline & Deltoid & 0 & $\% 0.0$ & 2 & $\% 4.4$ & 2 & & \\
\hline & Rektusfemoris & 0 & $\% 0.0$ & 0 & $\% 0.0$ & 0 & & \\
\hline \multirow[t]{5}{*}{ En Az Uygulandığı Bölge } & Dorsogluteal & 2 & $\% 4.4$ & 5 & $\% 11.1$ & 7 & 2.429 & 0.691 \\
\hline & Ventrogluteal & 18 & $\% 40.0$ & 18 & $\% 40.0$ & 36 & & \\
\hline & Vastuslateralis & 3 & $\% 6.7$ & 1 & $\% 2.2$ & 4 & & \\
\hline & Deltoid & 18 & $\% 40.0$ & 18 & $\% 40.0$ & 36 & & \\
\hline & Rektusfemoris & 4 & $\% 8.9$ & 3 & $\% 6.7$ & 7 & & \\
\hline \multirow[t]{5}{*}{ En Güvenli Bölge } & Dorsogluteal & 26 & $\% 57.8$ & 32 & $\% 71.1$ & 58 & 3.154 & 0.244 \\
\hline & Ventrogluteal & 17 & $\% 37.8$ & 13 & $\% 28.9$ & 30 & & \\
\hline & Vastuslateralis & 0 & $\% 0.0$ & 0 & $\% 0.0$ & 0 & & \\
\hline & Deltoid & 0 & $\% 0.0$ & 0 & $\% 0.0$ & 0 & & \\
\hline & Rektusfemoris & 2 & $\% 4.4$ & 0 & $\% 0.0$ & 2 & & \\
\hline \multirow[t]{2}{*}{ Yeterli Bilgiye Sahip OIma } & Evet & 38 & $\% 84.4$ & 34 & $\% 75.6$ & 72 & 0.292 & 0.43 \\
\hline & Hayır & 7 & $\% 15.6$ & 11 & $\% 24.4$ & 18 & & \\
\hline \multirow[t]{2}{*}{ Hava Kilidi Kullanma Durumu } & Evet & 25 & $\% 55.6$ & 22 & $\% 48.9$ & 47 & 0.401 & 0.673 \\
\hline & Hayır & 20 & $\% 44.4$ & 23 & $\% 51.1$ & 43 & & \\
\hline \multirow[t]{2}{*}{ Z Tekniği Kullanma } & Evet & 19 & $\% 42.2$ & 23 & $\% 51.1$ & 42 & 0.714 & 0.526 \\
\hline & Hayır & 26 & $\% 57.8$ & 22 & $\% 48.9$ & 48 & & \\
\hline Okulda Ventrogluteal Bölgeye & Evet & 16 & $\% 35.6$ & 14 & $\% 31.1$ & 30 & 0.20 & 0.823 \\
\hline $\begin{array}{l}\text { llişkin Demonstrasyon } \\
\text { Uygulaması Yapma Durumu }\end{array}$ & Hayır & 29 & $\% 64.4$ & 31 & $\% 68.9$ & 60 & & \\
\hline \multirow[t]{3}{*}{ En Son Alınan Eğitim } & Almadım & 15 & $\% 33.3$ & 19 & $\% 42.2$ & 34 & 3.137 & 0.217 \\
\hline & $0-12 a y$ & 0 & $\% 0.0$ & 2 & $\% 4.4$ & 2 & & \\
\hline & 13 ay ve üstü & 30 & $\% 66.7$ & 24 & $\% 53.3$ & 54 & & \\
\hline
\end{tabular}

Fisher Exact Test (Monte Carlo) - Pearson Chi Square Test(Monte Carlo) ${ }^{*} \mathrm{p}<0.05$ 
Tablo 3. Deney ve kontrol grubundaki hemşirelerin ve ebelerin ventrogluteal bölge kullanma durumlarının değerlendirilmesi

\begin{tabular}{|c|c|c|c|c|c|c|c|c|c|}
\hline & \multicolumn{9}{|c|}{ Grup } \\
\hline & & \multicolumn{2}{|c|}{ Deney } & \multicolumn{2}{|c|}{ Kontrol } & \multicolumn{2}{|l|}{$\begin{array}{l}\text { Toplam } \\
(n=90)\end{array}$} & \multirow[t]{2}{*}{$X^{2}$} & \multirow[t]{2}{*}{$p$} \\
\hline & & $n$ & $\%$ & $n$ & $\%$ & & & & \\
\hline \multirow[t]{2}{*}{ VG Kullanma } & Evet & 13 & $\% 28.9$ & & 11 & $\% 24.4$ & 24 & 0,227 & 0.812 \\
\hline & Hayır & 32 & $\% 71.1$ & & 34 & $\% 75.6$ & 66 & & \\
\hline \multirow{11}{*}{$\begin{array}{l}\text { VG Kullanmama } \\
\text { Nedenleri** }\end{array}$} & Alışkanlık & 7 & $\% 21.9$ & & 5 & $\% 14.7$ & 12 & 23,938 & $0.001^{*}$ \\
\hline & Bilgi eksikliği & 8 & $\% 25.0$ & & 20 & $\% 58.8$ & 28 & & \\
\hline & Yeterli demonstrasyonun olmaması & 0 & $\% 0.0$ & & 1 & $\% 2.9$ & 1 & & \\
\hline & Güvenli olmadığı için & 6 & $\% 18.8$ & & 0 & $\% 0.0$ & 6 & & \\
\hline & Hasta memnuniyeti & 0 & $\% 0.0$ & & 2 & $\% 5.9$ & 2 & & \\
\hline & Ağrilı bir uygulama & 0 & $\% 0.0$ & & 1 & $\% 2.9$ & 1 & & \\
\hline & Yorum yok & 7 & $\% 21.9$ & & 1 & $\% 2.9$ & 8 & & \\
\hline & $\begin{array}{l}\text { Yeterli demonstrasyonun olmaması ve } \\
\text { bilgi eksikliği }\end{array}$ & 2 & $\% 6.3$ & & 2 & $\% 5.9$ & 4 & & \\
\hline & Bilgi eksiliği ve güvenli olmadığı için & 1 & $\% 3.1$ & & 0 & $\% 0.0$ & 1 & & \\
\hline & Bilgi eksikliği ve alışkanlık & 1 & $\% 3.1$ & & 0 & $\% 0.0$ & 1 & & \\
\hline & Bilgi eksikliği ve hasta memnuniyeti & 0 & $\% 0.0$ & & 2 & $\% 5.9$ & 2 & & \\
\hline
\end{tabular}

Hemşirelerin ve ebelerin intramüsküler uygulamalarda "VG bölgeyi kullanmama nedeniniz nedir?" sorusuna verdikleri cevaplar incelendiğinde; deney grubunun \%25'inin bilgi eksikliği, kontrol grubunun yarısından fazlasının bilgi eksikliği cevabını verdiği ve gruplar arasında istatistiksel olarak anlamlı bir fark olduğu saptandı ( $p=0.001$; Tablo 3 ).

Hemşirelerin ve ebelerin ventrogluteal bölgeye ilişkin soruların toplam puanların eğitim öncesi ve eğitim sonrası dağılımları gruplara göre incelendiğinde; deney grubunun eğitim öncesi puan ortalamasının 14.29 \pm 8.34 olduğu, eğitim sonrası puan ortalamasının $23.53 \pm 3.14$ olduğu ve aralarında istatistiksel olarak anlamlı fark olduğu saptandı $(p=0.001)$. Kontrol grubunun eğitim öncesi puan ortalamasının $10.38 \pm 8.87$ olduğu, eğitim sonrası puan ortalamasının $18.76 \pm 6.80$ olduğu ve aralarında istatistiksel olarak anlamlı fark olduğu saptandı $(p=0.001)$. Grupların eğitim sonrası değişim puanları ve eğitim öncesi değişim puanları arasındaki fark değerlendirildiğinde deney grubunun ortalama toplam değişim puanı $(9.24 \pm 8.38)$, kontrol grubunun ortalama toplam değişim puanları $(8.38 \pm 8.95)$ arasında anlamlı bir fark saptanmadı ( $p=0.637$; Tablo 4$)$.
Tablo 4. Ventrogluteal bölgeye ilişkin bilgi puan ortalamalarının

karşılaştırıması

\begin{tabular}{|c|c|c|c|c|}
\hline & Deney (45) & Kontrol (45) & & \\
\hline & Ortalama $\pm S S$ & Ortalama $\pm S S$ & $F^{a}$ & $P$ Değeria \\
\hline \multicolumn{5}{|l|}{ Toplam } \\
\hline Eğitim Öncesi & $14.29 \pm 8,34$ & $10.38 \pm 8.87$ & & \\
\hline Eğitim Sonrası & $23.53 \pm 3,14$ & $18.76 \pm 6.80$ & & \\
\hline P Değerib & $0.001^{*}$ & $0.001^{*}$ & & \\
\hline$F^{b}$ & 54.755 & 39.451 & & \\
\hline Değişim (Son-ilkk) & $9.24 \pm 8.38$ & $8.38 \pm 8.95$ & 0.225 & 0.637 \\
\hline
\end{tabular}

Eğitimden bir ay sonra deney ve kontrol grubundaki hemşirelerin ve ebelerin intramüsküler enjeksiyon uygulamasında kullandıkları bölgelerin dağııımı incelendiğinde; deney grubunun \%62.2'sinin dorsogluteal bölgeyi, \%26.7'sinin ventrogluteal bölgeyi; kontrol grubunun \%80' inin dorsogluteal bölgeyi, \%13.3'ünün ventrogluteal bölgeyi, kullandığı, gruplar arasında istatistiksel olarak anlamlı bir fark olmadığı saptandı ( $p=0.961$; Tablo 5). 


\begin{tabular}{|c|c|c|c|c|c|c|c|}
\hline & \multicolumn{7}{|c|}{ Grup } \\
\hline & \multicolumn{2}{|c|}{ Deney } & \multicolumn{2}{|c|}{ Kontrol } & \multirow[t]{2}{*}{ Toplam $(n=90)$} & \multirow[t]{2}{*}{$X^{2}$} & \multirow[t]{2}{*}{$p$} \\
\hline & $n$ & $\%$ & $n$ & $\%$ & & & \\
\hline Dorsogluteal Bölge & 28 & $\% 62.2$ & 36 & $\% 80.0$ & 64 & 3.500 & 0.186 \\
\hline Ventrogluteal Bölge & 12 & $\% 26.6$ & 6 & $\% 13.3$ & 18 & & \\
\hline Vastuslateralis Bölgesi & 5 & $\% 11.1$ & 3 & $\% 6.7$ & 8 & & \\
\hline Deltoid Bölge & 0 & $\% 0.0$ & 0 & $\% 0.0$ & 0 & & \\
\hline \multirow[t]{3}{*}{ Rektusfemoris Bölgesi } & 0 & $\% 0.0$ & 0 & $\% 0.0$ & 0 & & \\
\hline & & $Z:-0.056$ & & Z: -2.762 & & & \\
\hline & & p: 0.961 & & $\mathrm{p}: 0.003^{*}$ & & & \\
\hline
\end{tabular}

Fisher Exact Test (Monte Carlo) - Pearson Chi Square Test(Monte Carlo) - Wilcoxon Signed Ranks Test ${ }^{*} p<0.05$

\section{Tartışma}

Deney ve kontrol grubundaki hemşirelerin ve ebelerin intramüsküler uygulamalarında kullandıkları bölge ile en güvenli bölgelere göre incelendiğinde; deney grubunun en çok dorsogluteal bölgeyi (\%95.6) kullandığı, en güvenli bölgenin ise \%57.8 ile dorsogluteal bölge (DG) ve ikinci sırada \%37,8 ile ventrogluteal bölge olduğu; kontrol grubunun en çok dorsogluteal bölgeyi (\%88.9) kullandığı, en güvenli bölgenin \%71.1 ile dorsogluteal bölge ve ikinci sırada \%28.9 ile ventrogluteal bölgenin olduğu saptandı. Floyd ve Meyer (2007) tarafından yapılan çalışmada hemşirelerin \%99'unun dorsogluteal bölgeyi, \%97'sinin deltoid kasını, \%87'sinin vastuslateralis kasını sadece \%9'unun ventrogluteal bölgeyi intramüsküler enjeksiyon amacıyla kullandıklarını; Güneş vd. (2009) hemşirelerin \%60'ının enjeksiyon uygulamalarında her zaman dorsogluteal bölgeyi kullandığını, \%78.2'sinin ventrogluteal bölgeyi hiçbir zaman kullanmadıklarını; Gülnar (2012) hemşirelerin \%85.9'unun IM enjeksiyon uygulamasında en sık DG bölgeyi kullandığı, sadece \%7.4'ünün VG bölgeyi kullandığı ve vastus lateralis kası ve deltoid kas gibi diğer enjeksiyon bölgelerinin daha az sıklıkla kullanıldığını; Tuğrul ve Denat (2014) hemşirelerin \%48.2'sinin intramüsküler enjeksiyonda her zaman dorsogluteal alanı kullandıklarını, ventrogluteal alanı (\%38.8), deltoid kası (\%65.9), laterofemoral alanı (\%52.9), rektus femoris kasını (\%68.2) hiçbir zaman kullanmadıklarını ve \%47.1' inin enjeksiyon alanı olarak ventrogluteal alanı en güvenli bulduklarını, daha sonra sırasıyla \%36.5'i dorsogluteal alanı, \%5.9'u laterofemoral alanı olduğunu bildirmiştir $(8,11,17,18)$. Araştırma sonuçlarımız literatürle paralellik göstermektedir. Literatürde ventrogluteal bölgenin kas içi enjeksiyon için en güvenli bölge olduğu belirtilse de, sağlık personellerinin kalça bölgesinde DG bölgeyi kullandığı bildirilmektedir $(9,14,15)$. Çalışmamızda, hemşirelerin ve ebelerin tamamına yakını IM uygulamalarda en çok dorsogluteal bölgeyi tercih etmektedir. Dorsogluteal bölgenin intramüsküler enjeksiyonlarda en çok kullanılma ve en güvenli bölge olarak söylenme nedeninin hemşirelerin ve ebelerin VG bölgenin avantajları ve literatürdeki intramüsküler enjeksiyon uygulamalarındaki gelişmeler konusundaki bilgi yetersizliğine, VG alana enjeksiyon uygulanması ile ilgili yeterli demonstrasyonun yapılmamasına ve hastaların ventrogluteal bölge kullanımına alışkın olmamalarına, dolayısıyla yanlış yere enjeksiyon yapıldığını düşünmelerine bağlı olduğu söylenebilir.

Deney grubundaki hemşirelerin ve ebelerin $\% 84.4$ 'ünün intramüsküler uygulamalar konusunda yeterli bilgiye sahibi olduğu, \%55.6'sının hava kilidi tekniğini kullandığı, \%57.8'inin Z tekniğini kullanmadığı; kontrol grubundaki hemşirelerin ve ebelerin \%75.6'sının intramüsküler uygulamalar konusunda yeterli bilgiye sahibi olduğu, \%51.1'inin hava kilidi tekniğini kullanmadığı, \%51.1'inin Z tekniğini kullandığı saptandı. Altıok vd. (2007) yaptıkları çalışmada ebe ve hemşirelerin \%17'sinin intramüsküler enjeksiyonda "Z" tekniğini kullandığını, Güneş vd. (2009) hemşirelerin \%54.5'inin enjeksiyon uygulaması esnasında her zaman hava kilidi tekniğini kullandıklarını, \%14.5'inin her zaman intramüsküler enjeksiyon uygulaması esnasında Z tekniğini kullandıklarını bildirmiştir. Nicoll ve Hesby (2002), tüm IM ilaç uygulamalarında Z-yol tekniğin kullanılması gerektiğini bildirmiştir $(10,18,32)$. Literatürde, IM enjeksiyon sırasında uygulanan hava kilidi tekniğinin irritan ilaçların cilt altı dokusunu tahriş etme ve buna bağlı oluşabilecek enjeksiyon ağrısını azalttığı bildirilmektedir $(1,34,35,36)$. Çalışmamızdaki hemşirelerin ve ebelerin $Z$ 
yol tekniği ve hava kilidi tekniğini yeterli düzeyde kullanmadığı, deney ve kontrol grubundaki hemşireler ve ebeler intramüsküler enjeksiyon uygulamaları konusunda yeterli düzeyde bilgi sahibi olduklarını bildirseler de bu konudaki bilgilerinin istenilir düzeyde olmadığı söylenebilir.

Deney grubundaki hemşirelerin ve ebelerin \%66.7'sinin en son 13 ay ve üstü öncesinde eğitim aldığı ve \%64.4'ünün VG bölge tespiti konusunda demonstrasyon yapmadığı; kontrol grubundaki hemşirelerin ve ebelerin \%53.3'ünün 13 ay ve üstü öncesinde eğitim aldığı ve $\% 68.9^{\prime}$ unun VG bölge tespiti konusunda demonstrasyon yapmadığı saptandı. Hemşirelerin ve ebelerin konu ile ilgili uzun bir süre önce eğitim almış olmaları ve VG bölge tespiti konusunda demonstrasyon yapmamış olmaları klinikte, IM enjeksiyon uygulamalarında VG bölgeyi kullanmama nedenlerinden biri olduğu söylenebilir.

Hemşirelerin ve ebelerin intramüsküler uygulamalarda VG bölgeyi kullanma durumu incelendiğinde; deney grubunda \%71.1'inin, kontrol grubunda \%75.6'sının intramüsküler uygulamalarda VG bölgeyi kullanmadığı, VG bölgeyi kullanmama nedenleri incelendiğinde; deney grubunun bilgi eksikliğine (\%25), alışkanlığa (\%21.9) ve güvenli olmamasına (\%18.8) bağlı olduğu, kontrol grubunun bilgi eksikliğine (\%58.8) ve alışkanlığa bağlı (\%14.7) olduğu saptandı. Floyd ve Meyer (2007); hemşirelerin ventrogluteal enjeksiyon alanını seçmelerindeki isteksizliklerini; bu alanı belirlemenin zor olduğu, hemşirelik kitaplarının 1960'dan bu yana intramusküler enjeksiyon için dorsogluteal alanı anlattıklarını, alışık oldukları ve kullandıkları yöntemden farklı bir yöntemi kullanmaya adapte olmakta zorlandıklarını ve bu konuyla ilgili kanıtların özellikle pratikte gözlenmediyse uygulamalarını değiştirmek için yeterli olmadığını belirtmiştir (17). Bazı hemşirelik okullarında ventrogluteal enjeksiyon alanının öğretildiği fakat uygulamada nadiren yapıldığı belirtilmiştir. Klinik eğitimde genellikle enjeksiyon alanları seçilirken dorsogluteal alan (riskleri bilinmesine rağmen), deltoid alan ve laterofemoral alanın tercih edildiği bildirilmektedir. Gülnar (2012) hemşirelerin IM enjeksiyon uygulamasında VG bölgeyi kullanmama nedeni olarak, DG bölgeyi tercih etme (\%58.3), VG bölgesine ilişkin bilgi sahibi olmama (\%34.0) ve doğru bölgeyi tespit edememe (\%3.3) şeklinde bildirmiştir (11). Literatürdeki bilgiler ve yapılan araştırma sonuçları ile bulgularımız benzerlik göstermektedir. Konuyla ilgili geçmiş yıllarda okullarda verilen eğitim ve sahada çalışan hemşirelerin ve ebelerin çoğunluğunun eski mezunlardan oluştuğu düşünüldüğünde, elde edilen verilerin beklenen bir sonuç olduğu söylenebilir.
Hemşirelerin ve ebelerin ventrogluteal bölgeye ilişkin soruların toplam puanlarının grup içi eğitim öncesi ve eğitim sonrası dağılımları incelendiğinde; deney grubunun eğitim öncesi puan ortalamasının $14.29 \pm 8.34$ olup orta düzeyde olduğu, eğitim sonrası puan ortalamasının $23.53 \pm 3.14$ olup iyi düzeyde olduğu ve aralarında istatistiksel olarak anlamlı fark olduğu saptandı $(p=0.001)$; kontrol grubunun eğitim öncesi puan ortalamasının $10.38 \pm 8.87$ olup düşük düzeyde olduğu, eğitim sonrası puan ortalamasının $18.76 \pm 6.80$ olup orta düzeyde olduğu ve aralarında istatistiksel olarak anlamlı fark olduğu saptandı. Altıok vd. (2007) birinci basamak temel sağlık hizmetinde (sağlık ocakları) çalışan ebe ve hemşirelerin IM enjeksiyonuna yönelik bilgilerini belirlemek amacıyla yaptıkları çalışmada ebe ve hemşirelerin IM enjeksiyona hazırlık, bölge seçimi ve uygulamalarına yönelik bilgilerinin orta düzeyde olduğunu saptamışlardır (32). Gülnar (2012) yaptığı çalışma sonucunda, hemşirelerin IM enjeksiyonda ventrogluteal bölgenin kullanımıyla ilgili 24 önermeye ilişkin bilgi puan ortalamasının 13.1 \pm 3.7 olduğunu bildirmiştir (11). Araştırma sonuçlarımız literatürle benzerlik göstermektedir. NLP bize alıştırma yapma, konuşma, yeni ve pozitif yönde davranmada yardım eder (37). Hemşirelerin eğitim öncesindeki bilgi düzeylerinin ortalamanın altında olduğu, eğitim sonrasında bilgi düzeylerinin ise iyi ve orta düzeye yükseldiği, yani hemşirelere iki farklı şekilde de verilen eğitimlerin bilgi düzeylerini olumlu yönde etkilediği söylenebilir.

Nöro Linguistik Programlama' nın öğrenci, öğretmen, yönetici ve toplulukların eğitimsel açıdan performansını geliştirmede etkili şekilde kullanılabileceği söylenmektedir (38). Hemşirelerin ve ebelerin ventrogluteal bölgeye ilişkin soruların toplam puanlarının gruplar arası eğitim öncesi ve eğitim sonrası değişim puanları incelendiğinde; deney grubundaki hemşirelerin ve ebelerin ortalama toplam değişim puanının $9.24 \pm 8.38$ olduğu, kontrol grubunun ortalama toplam değişim puanının $8.38 \pm 8.95$ olduğu ve aralarında istatistiksel olarak anlamlı bir fark olmadığı saptandı ( $p>0.05$ ). NLP ile ilgili yapılan birçok bilimsel çalışma olumlu sonuçlar vermiştir. Bardak (2009) NLP temelli bir öğretim programının "madde analizi" konusunun öğretiminde öğrencilerin akademik başarısına etkisini belirlemek amacıyla yaptığı çalışmasında deney ve kontrol gruplarının son test puan ortalamaları arasında istatistiksel açıdan anlamlı bir farklılık bulunduğunu, uygulanan ders planının faydalı olduğunu bildirmiş̧ir (22). Şen (2014) hemşirelerde el hijyeni davranışlarının kazanılmasında NLP tekniklerinin etkisini belirlemek amacıyla yaptığı çalışmasında, deney ve kontrol grubundaki hemşirelerin eğitim öncesi, eğitim sonrası ve eğitimden 1 ay 
sonra bilgi puan ortalamaları karşılaştırıldığında; istatistiksel olarak anlamlı fark olmadığını bildirmiştir $(p>0.05)$ (23). Çevik, Pakiş ve Eroğlu (2017) Santral venöz kateter uygulamaları ve kan kültürü alınması konusunda hemşirelere verilen eğitimde NLP tekniğinin etkili olduğunu saptamışlardır (29). Çalışma sonuçlarımız literatürü destekler nitelikte değildir.

Eğitimden bir ay sonra deney ve kontrol grubundaki hemşirelerin ve ebelerin intramüsküler enjeksiyon uygulamasında kullandıkları bölgelerin dağılımı incelendiğinde; deney grubunun \%62.2'sinin dorsogluteal bölgeyi, \%26.7'sinin ventrogluteal bölgeyi kullandığı; kontrol grubunun \%80'inin dorsogluteal bölgeyi, \%13.3'ünün ventrogluteal bölgeyi kullandığı ve gruplar arasında istatistiksel olarak anlamlı bir farklııı olmadığı saptandı. Floyd ve Meyer (2007) tarafından yapılan çalışmada hemşirelerin \%99'unun dorsogluteal bölgeyi, \%97'sinin deltoid bölgeyi, \%87'sinin vastuslateralis bölgesini, sadece $\% 9$ 'unun ventrogluteal bölgeyi intramüsküler enjeksiyon amacıyla kullandıklarını; Walsh (2011) yaptığı çalışmada hemşirelerin tercihen ventrogluteal bölge yerine dorsogluteal bölgeyi tercih ettiklerini belirtmiş ve yönetici hemşirelerin VG bölge kullanımını ve konfor seviyesini arttırmayı amaçlayan stratejiler geliştirilmesine odaklanması gerektiğini bildirmiştir $(17,39)$. Yapılan çalışmalarda ventrogluteal bölgeye enjeksiyon uygulama oranının düşük olduğu görülmektedir. Ancak çalışmamız sonucunda eğitim öncesinde hemşirelerin ve ebelerin intramüsküler enjeksiyon uygulamalarında ventrogluteal bölgeyi daha az kullandıkları görülürken, eğitimden bir ay sonra hem deney grubunda hemde kontrol grubunda artış olduğu görülmektedir. İntramüsküler enjeksiyon uygulamasında VG bölgenin tercih edilmemesinin ve VG bölge kullanımına ilişkin davranış değişikliğinin sağlanamamasının nedeni, hemşire ve ebelerin çalışma hayatı boyunca aldıkları eğitim doğrultusunda dorsogluteal bölgeyi kullanma alışkanlıklarına, hastaların da aynı şekilde enjeksiyon uygulamasında dorsogluteal bölgeye alışkın olmalarına ve ventrogluteal bölgeye uygulanması durumunda yanlış uygulama yapıldığı inancına sahip olmaları ile bu bölgenin kullanımı konusunda kurum tarafından da hemşire ve ebelerin yeterli düzeyde teşvik edilmemesine bağlı olduğu söylenebilir. Çalışma sonuçlarımız literatür ile benzerlik göstermemektedir. Hemşirelerin ve ebelerin eğitim aldıkları dönemdeki bilgiler ile şu anki bilgilerin farklı olmasına, literatür bilgilerinin güncellenmesine bağlı olduğu, bu doğrultuda sağlık profesyonellerinin alanlarındaki gelişmeleri yakından takip etmesi ve bilgilerini güncellemeleri gerektiği düşünülmektedir.

\section{Sonuç ve öneriler}

Araştırmanın sonucunda deney ve kontrol grubunda;

- Deney grubunda eğitim öncesi ve eğitim sonrasında ventrogluteal bölgeye ilişkin bilgi düzeyi puan ortalamaları karşılaştırıldığında istatistiksel olarak anlamlı fark olduğu,

- Kontrol grubunda eğitim öncesi ve eğitim sonrasında ventrogluteal bölgeye ilişkin bilgi düzeyi puan ortalamaları karşılaştııılığında istatistiksel olarak anlamlı fark olduğu,

- Deney ve kontrol grubu arasında eğitim öncesi ve eğitim sonrasında ventrogluteal bölgeye ilişkin bilgi düzeyi puan ortalamalarının değişim puanları arasında anlamlı bir fark olmadığı saptandı.

Elde edilen sonuçlar doğrultusunda; hemşirelik ve ebelik öğrencilerine IM enjeksiyonlarda ventrogluteal bölge kullanımı ile ilgili verilen demonstrasyon sayısının arttırılması ve alanlarda bire bir öğrencilere bu uygulamanın gösterilmesi, hemşirelik ve ebelik öğrencilerinin IM enjeksiyon uygulamalarında ventrogluteal bölge kullanımına teşvik edilmesi ve öneminin vurgulanması, sağlık çalışanlarının yıllık hizmetiçi eğitim planına bu konunun eklenmesi ve alandaki yeniliklerin tartışılması, sağlık çalışanlarının intramüsküler enjeksiyon uygulamasına ilişkin son yenilikleri yakından takip etmesi, ventrogluteal bölgeye enjeksiyon uygulanması durumunda, hastaların yanlış bölgeye enjeksiyon uygulandığına ilişkin endişelerini (yanlış inançlarını) azaltmak/yok etmek amacıyla uygulama öncesi bu bölgenin avantajları konusunda eğitim verilmesi, yeni mezun hemşirelerin oryantasyon eğitimlerine bu konunun eklenmesi, lisans eğitim müfredatında ventrogluteal alana ilişkin enjeksiyon uygulamasına daha fazla ağırlık verilmesi, benzer araştırmanın farklı ve daha geniş bir örneklem grubu ile daha önce NLP eğitimi almış kişilerle çalışılması önerilmektedir. 


\section{Kaynaklar}

1. Öçal H. Kas İçi Enjeksiyonlarda Ağrı, Kanama ve Hematom Gelişimi Açısından Dorsogluteal ve Ventrogluteal Bölgelerin Karşılaştııılması. Yayınlanmamış Yüksek Lisans Tezi, Marmara Üniversitesi Sağlık Bilimleri Enstitüsü, İstanbul 2012.

2. Kaya N, Turan N, Palloş AÖ. Dorsogluteal Bölge İntramusküler Enjeksiyon Uygulamak Amacıyla Kullanılmamalı mı?. I.Ü.F.N. Hemşirelik Dergisi, 2012;20: 146-53.

3. Gülnar E, Çalışkan N. Hemşirelerin Ventrogluteal Bölgeye Intramüsküler Enjeksiyon Uygulamasına Yönelik Bilgi Düzeylerinin Belirlenmesi. Dokuz Eylül Üniversitesi Hemşirelik Yüksekokulu Elektronik Dergisi, 2014;7: 70-7.

4. Cornwall J. Are Nursing Students Safe When Choosing Gluteal Intramuscular Injection Locations?. Australasian Medical Journal, 2011;4:315-21.

5. Greenway K. Rituals in Nursing: Intramuscular Injections. Journal of Clinical Nursing, 2014;23: 3583-8. [CrossRef]

6. Mishra P, Stringer MD. Sciatic Nerve Injury From Intramuscular Injection: A Persistent and Global Problem. International Journal of Clinical Practice, 2010;64: 1573-9. [CrossRef]

7. Ünal V, Ünal EÖ, Emir A, Özer Y, Çağdır S. Enjeksiyon Nöropatisi Olgularına Adli Tıbbi Yaklaşım. Adli Tıp Bülteni, 2015;20: 14-20. [CrossRef]

8. Tuğrul E, Denat Y. Hemşirelerin Ventrogluteal Alana Enjeksiyon Uygulamaya İlişkin Bilgi, Görüş ve Uygulamaları. Dokuz Eylül Üniversitesi Hemşirelik Yüksekokulu Elektronik Dergisi, 2014;7:275-84.

9. Kara D, Uzelli D, Karaman D. Using Ventrogluteal Site in Intramuscular Injections is a Priority or an Alternative?. International Journal of Caring Sciences, 2015;8: 507-13.

10. Nicoll LH, Hesby A. Intramuscular Injection: An Integrative Research Review and Guideline for Evidence-Based Practice. Applied Nursing Research, 2002;15: 49-62.

11. Gülnar E. Hemşirelerin İntramüsküler Enjeksiyonda Ventrogluteal Bölgenin Kullanımına Yönelik Bilgi Düzeylerinin Belirlenmesi. Gazi Üniversitesi Sağlık Bilimleri Enstitüsü, Ankara 2012.

12. Güneş ÜY, Zaybak A, Tamsel S. Ventrogluteal Bölgenin Tespitinde Kullanılan Yöntemin Güvenilirliğinin İncelenmesi. C. Ü. Hemşirelik Yüksekokulu Dergisi, 2008;12: 1-8.

13. Dinç L. Parenteral İlaçlar. İçinde Klinik Uygulama Becerileri ve Yöntemleri Aştı TA, Karadağ A, (Eds.), Adana, Türkiye: Adana Nobel Kitabevi Yayın Dağıtım ve Pazarlama Ltd. Şti., 2011; ss: 693-761.

14. Potter AP, Perry AG, Stockert AP, Hall MA. Fundamentals of Nursing, Ed. St. Lous Missouri, Canada, Mosby Inc. 2013.

15. Kaya N, Palloş A. Parenteral İlaç Uygulamaları. İçinde: Hemşirelik Esasları Hemşirelik Bilimi ve Sanatı 2, Aştı TA, Karadağ A, (Eds.), 1. Baskı, İstanbul, Türkiye: Akademi Basım ve Yayıncılık, 2014; 767-817.

16. Greenway K. Using the Ventrogluteal Site for Intramuscular Injection. Nursing Standard, 2004;18: 39-42. [CrossRef]

17. Floyd S, Meyer A. Intramuscular Injections - What's Best Practice. Why is There Such a Gap Between What is Taught in Nursing Schools about the Best Sites End Technique for Intramuscular Injections and What Actually Happens in Practice? Two Nurses Decided to Find Out. Kai Tiaki: Nursing New Zealand, 2007;13: 20-2.

18. Güneş ÜY, Zaybak A, Biçici B, Çevik K. Hemşirelerin İntramüsküler Enjeksiyon İşlemine Yönelik Uygulamalarının İncelenmesi. Atatürk Üniversitesi Hemşirelik Yüksekokulu Dergisi, 2009;12: 84-90.

19. Topal FE, Yıldırım B. The Assessment of Distances of Intramüsküler Injection Location From Some Landmarks in the Students of Muğla School of Health Sciences. Cumhuriyet Tıp Dergisi, 2014;36: 206-13. [CrossRef]
20. Alder H. Zarife Biliz (Çev) NLP: Yüksek Performansa Ulaşmanın Yeni Bilimi ve Sanatı, 2. Basım, İstanbul, Türkiye, Sistem Yayıncılık A.Ş., 2013.

21. Taştan K, Set T, Çayır Y. Nöro Linguistik Programlama ve Aile Hekimliğinde Kullanımı. Konuralp Tıp Dergisi, 2014;6: 63-6.

22. Bardak KA. NLP Temelli Bir Öğretim Programının "Madde Analizi" Konusunun Öğretiminde Öğrencilerin Akademik Başarısına Etkisi (Fırat Üniversitesi Örneği). Yayınlanmamış Yüksek Lisans Tezi, Fırat Üniversitesi Sosyal Bilimler Enstitüsü Eğitim Bilimleri Anabilim Dalı, Elazığ, 2007.

23. Şen S. Hemşirelerde El Hijyeni Davranışlarının Kazanılmasında Nöro Linguistik Programlama (NLP) Tekniklerinin Etkisi. Yayınlanmamış Doktora Tezi, İstanbul Üniversitesi Sağlık Bilimleri Enstitüsü, İstanbul, 2014.

24. Gün N. NLP Zihninizi Kullanma Kılavuzu. İstanbul, Türkiye: 43. Baskı, Kuraldışı Yayıncılık, 2015.

25. O'connor J. (Çev): Savaş Şenel. NLP Çalışma Kitabı, 1. Baskı, İstanbul, Türkiye: Arıtan Yayınevi 2014.

26. Aytaç S. İş Yaşamında Başarının Sırrı: NLP Tekniği. İş, Güç Endüstri Illişkileri ve İnsan Kaynakları Dergisi, 2000;2.

27. Aydemir, BAÇ. İşletmelerde Hedef Belirleme ve Etkili İletişimde NLP. Yönetim Bilimleri Dergisi, 2010;8: 95-116.

28. Kozanlı S. NLP ile Öğrenmeyi Öğrenmek ve Başarmak, 1. Basım, Bursa, Türkiye: Sentez Yayın ve Dağ. Eğitim ve Öğretim Kur. Tic. ve San. A.Ş. 2008.

29. Çevik K, Pakiş Çetin S, Eroğlu. Effects of the Neuro-Linguistic Programing Technique Used in the Education Given to Nurses about Central Venous Applications and Blood Culture Collection on Their Knowledge Level. Clin Exp Health Sci., 2017;7: 139-45.

30. Ulusoy F, Görgülü RS. İlaçların Uygulanması. İçinde: Hemşirelik Esasları-Temel Kuram, Kavram, Illke ve Yöntemler, Cilt 1, Ankara, Türkiye: Çağın Ofset, 1995;165-200.

31. Akbayrak N. Parenteral Yol ile İlaçların Verilmesi. İçinde Hemşirelik Esasları, 8. Baskı, Ankara, Türkiye: Damla Matbaacılık Rek. ve Yay. Tic. Ltd. Şti, 2000;227-52.

32. Altıok M, Kuyurtar F, Gökçe H, Taşdelen B. Birinci Basamak Sağlık Hizmetinde Çalışan Ebe ve Hemşirelerin Intramuskuler Enjeksiyonuna Yönelik Bilgileri. Fırat Sağlık Hizmetleri Dergisi, 2007;2: 69-84.

33. Yavuz $D E$, Karabacak Ü. İntramüsküler Enjeksiyonda Neden Ventrogluteal Bölgeyi Tercih Etmeliyiz?. Hemşirelikte Araştırma Geliştirme Dergisi, 2011;2: 81-8.

34. Kara D. İntramüsküler Enjeksiyona Bağlı Gelişen Ağrının Azaltılmasına Yönelik Yöntemler. Gümüşhane Üniversitesi Sağlık Bilimleri Dergisi, 2013; 2: 169-82.

35. Süzen B, Ay F. Illaç Uygulamaları. İçinde: Sağlık Uygulamalarında Temel Kavramlar ve Beceriler Ay F, (Eds.), 5. Baskı, İstanbul, Türkiye: Nobel Tıp Kitabevleri Ltd. Şti., 2013;422-509.

36. Engstrom JL, Giglio NN, Takacs SM, Ellis MC, Cherwenka DI. Procedures Used to Prepare and Administer Intramuscular Injections: A Study of Infertility Nurses. Journal of Obstetric Gynecologic and Neonatal Nursing, 2000;29: 159-68.

37. İnan D, Üstünlüoğlu E. Connecting NLP and Poetry Writing in the Language Class. Hasan Ali Yücel Eğitim Fakültesi Dergisi, 2004;2:57-67.

38. Özmen F, Aslan C. Sinir Dili Programlamanın (SDP) Eğitim Yönetimi ve Denetiminde Kullanılması. E-Journal of New World Sciences Academy, 2008;3: 226-37.

39. Walsh L, Brophy K. Staff Nurses' Sites of Choice for Administering Intramuscular Injections to Adult Patients in the Acute Care Setting. Journal of Advanced Nursing, 2011;67: 1034-40. [CrossRef] 